\title{
Electron microscopy of a rhabdomyosarcoma of the ear
}

\author{
I. FRIEDMAN, D. F. N. HARRISON, W. N. TUCKER, AND E. S. BIRD \\ From the Institute of Laryngology and Otology, London
}

SYNOPSIS The fine structure of a case of differentiated rhabdomyosarcoma of the ear is described. Characteristic actomyosin filaments have been demonstrated in thin sections showing cross-striation ( $\mathrm{Z}$ bands). There were large numbers of ribonucleoprotein particles but no virus-like particles present. It is hoped that, as in other difficult or rare tumours, electron microscopy may provide an additional clue of some assistance to the pathologist in determining diagnosis or aetiology.

Rhabdomyosarcoma of the ear is rare; only 12 cases have been reported in the available literature by Söderberg (1933), Gellerstedt (1938), Maconie (1944), Karatay (1949), Stobbe and Dargeon (1950), Eibergen (1952), Holman (1956), Blanchard and House (1957), Horn and Enterline (1958), and by Mehra (1960), all in young children who died within a few months of the first signs of the tumour.

A case of rhabdomyosarcoma of the ear in a 14-month-old boy provided the material for the present electron microscopic study of this unusual tumour.

Although the fine structure of a differentiated and an embryonal orbital rhabdomyosarcoma was described by Kroll, Kuwabara, and Howard in 1963, the fine structure of rhabdomyosarcoma of the ear has not yet been reported.

\section{CASE HISTORY}

\begin{abstract}
A.L., a boy born on 31 February 1962, was seen in November 1962 at Southampton General Hospital with a large cystic swelling behind the right auricle. Microscopical investigation of some granulations removed from the external auditory meatus and attic was inconclusive. In February 1963 he developed a fleshy aural polyp with facial palsy and was transferred to the associated Royal National Throat, Nose and Ear Hospital in London. Local excision of the aural mass and enlarged upper cervical lymph node was followed by treatment with $100 \mathrm{mg}$. of cyclophosphamide injected into the external carotid artery followed by $50 \mathrm{mg}$. daily intramuscularly and later by $25 \mathrm{mg}$. orally. There was marked local improvement and in June 1963 he was very well and the ear was dry. He was sent home where he died on 28 August 1963 with signs of cerebral damage. There was no post-mortem examination.
\end{abstract}

Received for publication 2 April 1964.
MATERIAL AND METHODS

Specimens of tissue from the tumour mass and lymph node were promptly fixed for both light and electron microscopy. Osmium-fixed tissue was embedded in

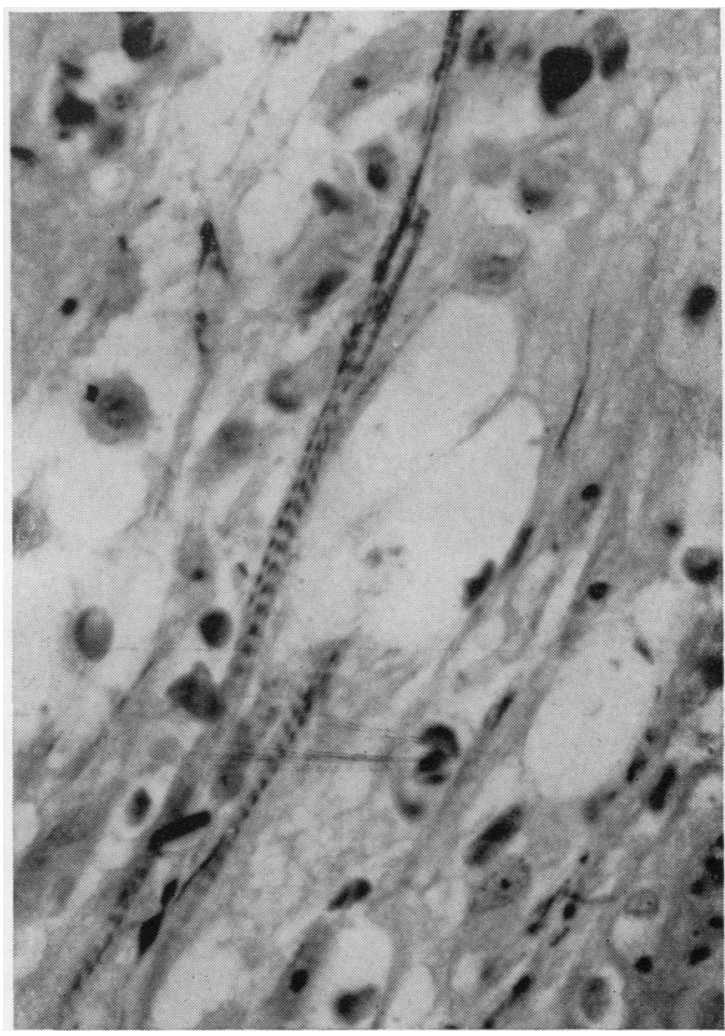

FIG. 1. Light microscopy of tumour tissue showing striated tumour cells. Phosphotungstic-acid haematoxylin stain. $\times 1,600$. 
FIG. 2. Groups of thick and thin filaments at higher magnification. Note interconnecting cross-bridges between myofilaments. $\times 152,000$.

Araldite (Glauert, Rogers, and Glauert, 1956), sectioned on a Huxley-type ultramicrotome, stained with leadmonoxide (Karnovsky, 1961), and examined under a Siemons Elmiskop I.

\section{LIGHT MICROSCOPY}

The neoplastic tissue is formed by irregularly arranged elongated cells and large rounded cells with abundant eosinophilic cytoplasm. A fairly large number of the elongated cells show crossstriation in sections stained with phosphotungstic acid haematoxylin (Fig. 1). The diagnosis is rhabdo- myosarcoma of the differentiated type. There is $\mathrm{a}$ secondary deposit of the tumour of similar morphos logy in the excised lymph node.

\section{ELECTRON MICROSCOPY}

There are various types of cells present in thin sections. Undifferentiated cells predominate and contain large aggregates of actomyosin formed b $\vec{D}$ randomly arranged myofilaments. The filament show varied orientation according to the different planes of sectioning, and appear to be of tw\& 


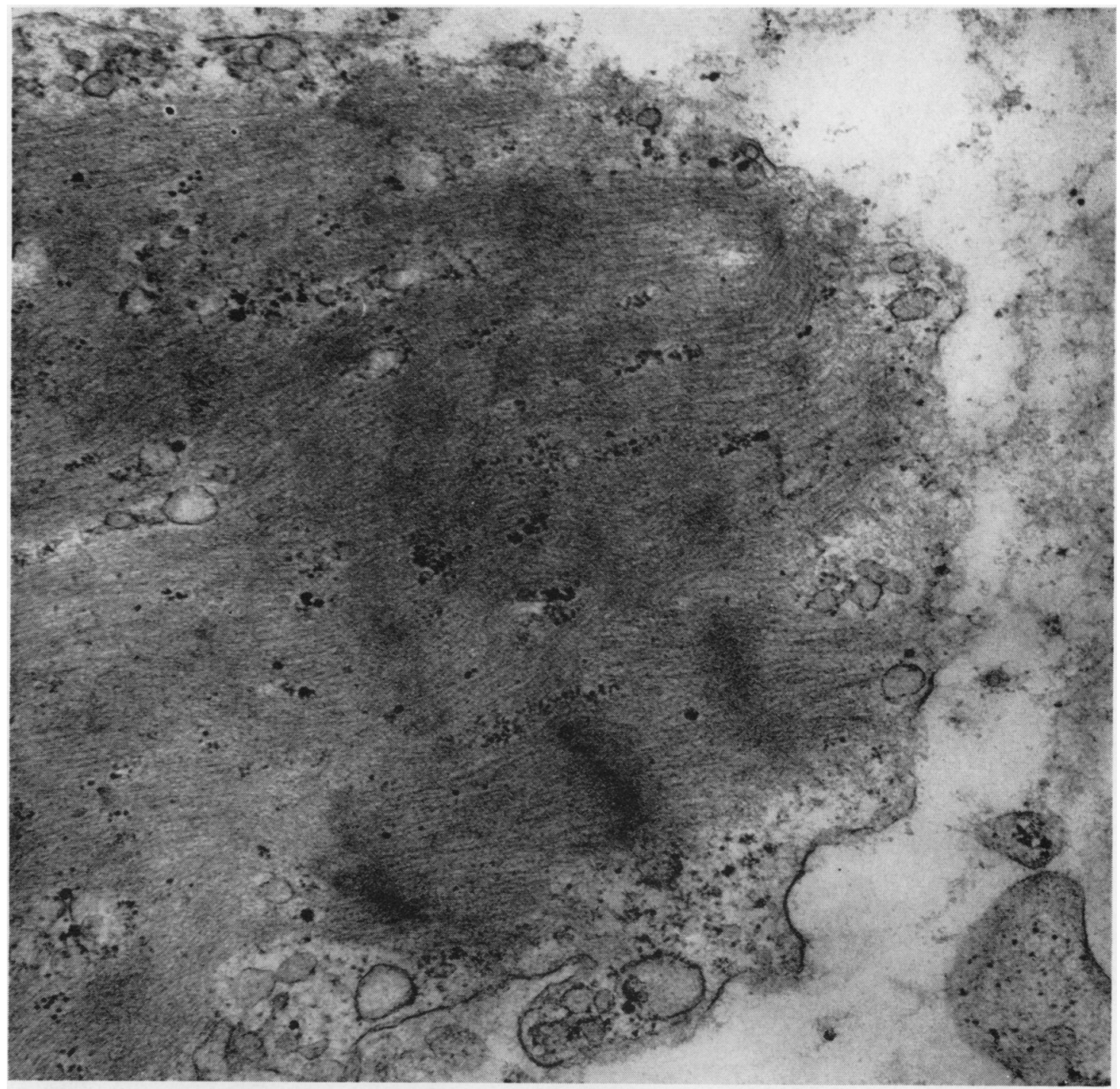

FIG. 3. Detail of tumour cell with large numbers of closely arranged actomyosin filaments and dark Z-bands.

There are numerous ribonucleoprotein and glycogen particles present. Note sarcotubules. $\times 45,000$.

calibres, one thick and approximately $150 \AA$ wide, the other thin and approximately $60-80 \AA$ wide (Fig. 2).

Cells are also present containing loosely arranged actomyosin filaments revealing darkly stained areas probably representing early stages of Z-bands.

In well-differentiated cells, however, the filaments are arranged in a more organized fashion and demonstrate the characteristic cross-striation of actomyosin (Figs. 3 and 4).

The dense $Z$-band can readily be recognized but the other bands are not clearly defined. There are interconnecting cross-bridges between the myofilaments (Fig. 2).

There are numerous groups of ribonucleoprotein and glycogen granules intermingled with the myofilaments. Several of the numerous mitochondria are vacuolated and closely associated with the actomyosin filaments and there are numerous sarcotubules present (Figs. 3 and 4).

The large crenated nuclei contain large nucleoli. There are no 'virus-like particles' present. 


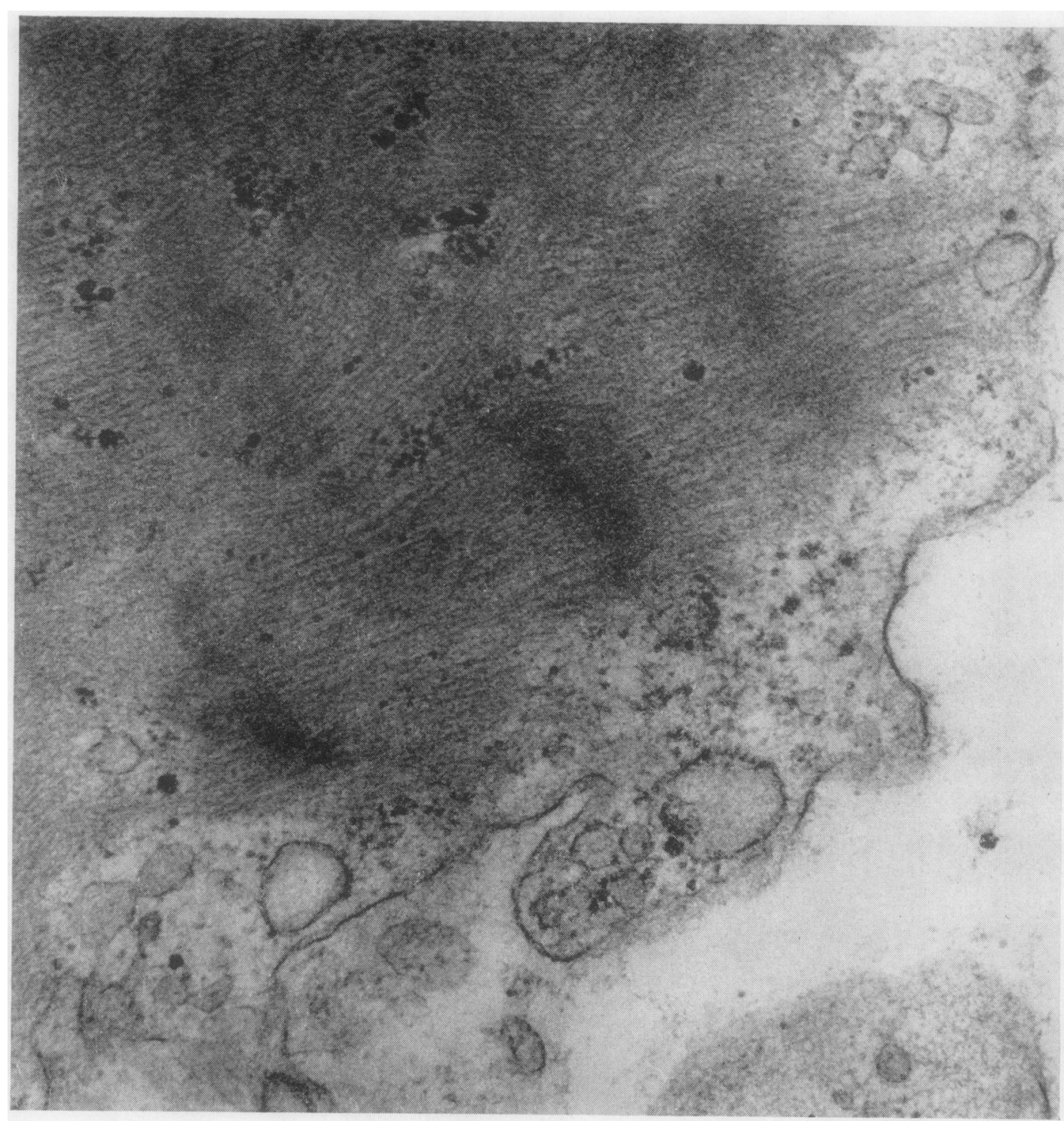

FIG. 4. Detail of Figure 3. $\times 90,000$.

\section{DISCUSSION}

Rhabdomyosarcomas are, on the whole, varied tumours and a recent review of Porterfield and Zimmerman (1962) revealed three types among the 55 cases studied: embryonal $(73 \%)$, differentiated $(11 \%)$, and alveolar $(16 \%)$.

Only 12 cases of rhabdomyosarcoma of the ear have so far been reported and the first detailed report of the fine structure of a differentiated rhabdomyosarcoma (of the orbit) has only recently been published by Kroll et al. (1963). The electron microscopic findings in the present case of rhabdo $-\overline{-}$ myosarcoma of the ear, the first case so examined? compare well with the case described by Kroll et af

The differentiated rhabdomyosarcoma consists of two main types of cells: (1) undifferentiated cells whose cytoplasmic actomyosin is in disordered array and (2) differentiated cells with well-organized striated actomyosin. Kroll et al. have considered tha f the more random the alignment of actomyosine filaments, the more poorly differentiated the cell. 


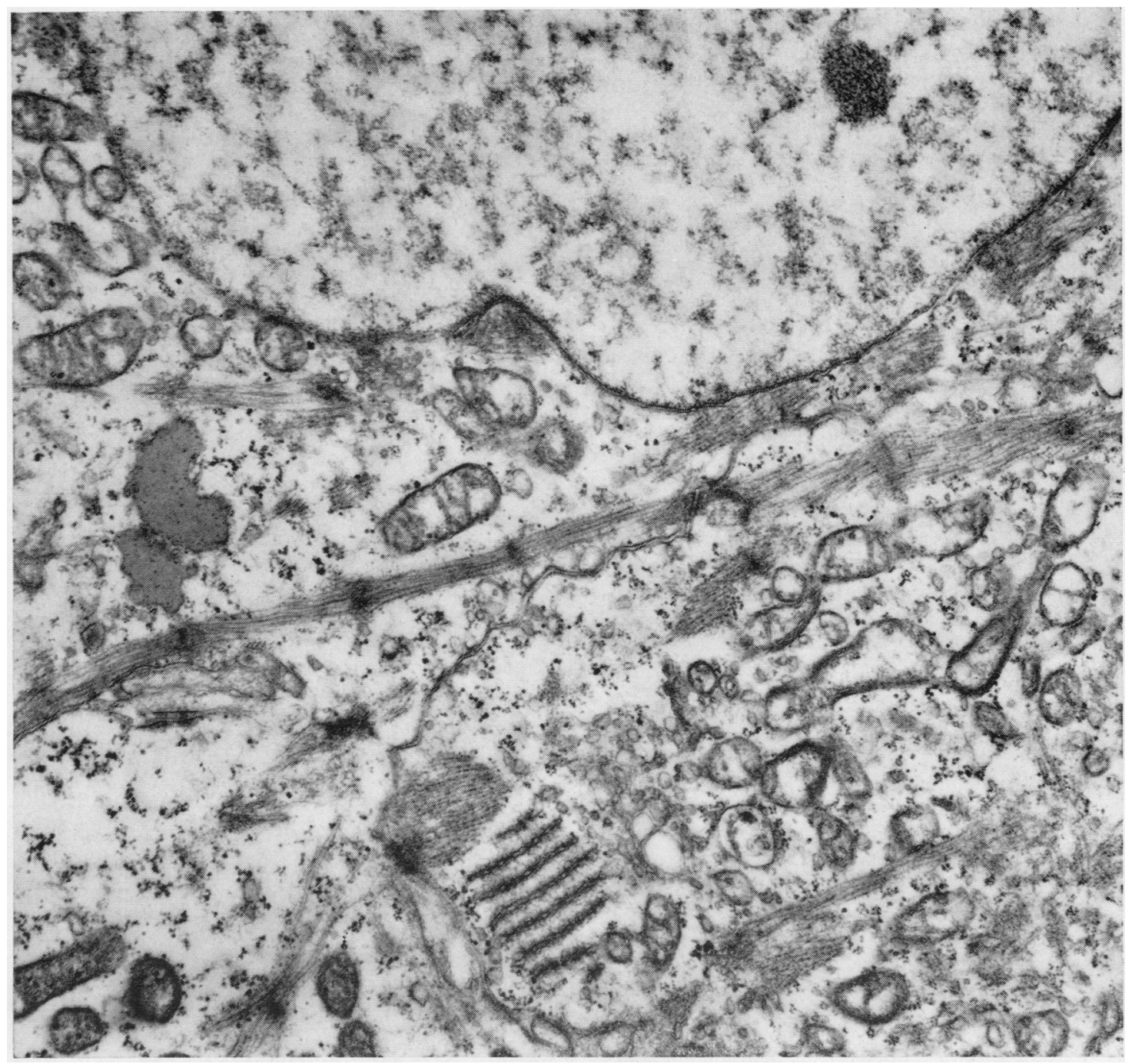

FIG. 5. Tissue culture of chick embryo myocardium. Developing muscle cell with some organized myofilaments showing Z-bands. Methacrylate embedding. $\times$ 24,500.

In the present example of differentiated rhabdomyosarcoma of the ear, there were numerous cells with loosely arranged actomyosin filaments and a smaller number of cells containing organized filaments displaying cross-striation which resemble in their ultrastructure cells of the chicken embryo myocardium (Fig. 5) grown in tissue culture (Meyer and Queiroga, 1959; Friedmann and Bird, unpublished observations). Kroll et al. had hoped, but were unable, to demonstrate actomyosin filaments in the cells of an embryonal type rhabdomyosarcoma of the orbit. Only further experience will show whether electron microscopy might in some instances reveal actomyosin filaments in certain cases of rhabdomyosarcoma in which no striation can be demonstrated under the light microscope.

The two types of actomyosin filaments are of some interest as it is frequently believed that the actin of muscle tissue is localized in the 'thin' filaments and that the 'thick' filaments contain the myosin.

The origin of the tumour has remained obscure. Willis (1948) suggested that rhabdomyosarcoma arose in embryonic tissue and that only rarely was adult skeletal muscle involved. Ashton (1958) suggested that these tumours should be classified as embryonal sarcomas. 
In this connexion it is interesting to note that Chapman, Jones, and Spelsberg (1963) described virus-like particles in two cases of orbital rhabdomyosarcoma which contained no myofilaments. There were no virus-like particles in the present case of differentiated rhabdomyosarcoma of the ear.

\section{REFERENCES}

Ashton, N. (1958). In Discussion to Blaxter, P. L., and Smith, J. L. Trans. ophth. Soc. U.K., 78, 83.

Blanchard, C. L., and House, H. P. (1957). Arch. Otolaryng., 66, 588. Chapman, G. B., Jones, I. S., and Spelsberg, W. W. (1963). Invest. Ophthal., 2, 538.

Eibergen, R. (1952). Ned. T. Geneesk, 96, 2007.

Friedmann, I., and Bird, E. S. Unpublished observations.
Gellerstedt, H. (1938). Acta path. microbiol. scand., suppl., 38, 55. 芌 Glauert, A. M., Rogers, G. E., and Glauert, R. H. (1956). Nature (Lond.), 178, 803.

Holman, R. L. (1956). J. Laryng., 70, 415.

Horn, R. C. Jr., and Enterline, H. T. (1958). Cancer (Philad.), 11, 181

Karatay, S. (1949). Arch. Otolaryng., 50, 330.

Karnovsky, M. J. (1961). J. biophys. biochem. Cytol., 11, 729.

Kroll, A. J., Kuwabara, T., and Howard, G. M. (1963). Inve Ophthal., 2, 523.

Maconie, A. C. (1944). J. Laryng., 59, 32.

Mehra, Y. N. (1960). Ibid., 74, 114.

Meyer, H., and Queiroga, L. T. (1959). J. biophys. biochem. Cytol., (ै),

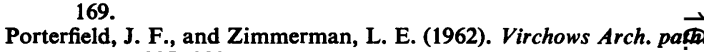
Anat., 335, 329.

Söderberg, F. (1933). Acta oto-laryng. (Stockh.), 18, 453.

Stobbe, G. D., and Dargeon, H. W. (1950). Cancer (Philad.), 3, 82\%

Willis, R. A. (1948). Pathology of Tumours, 1st ed., p. 739. Butterwortit: London.

\section{The November 1964 Issue}

\section{THE NOVEMBER 1964 ISSUE CONTAINS THE FOLLOWING PAPERS}

Cytology of the prostate M. K. MASON

Malignant lymphoma of the thyroid MARIE T. COX

Neoplasia of aortic intima R. A. SLADDEN

Intravascular endothelioma (endothelioma in situ, systemic endotheliomatosis) H. HABER, J. N. HARRISJONES, and A. L. WELLS

Some physiological characteristics of neomycin and kanamycin-resistant strains of Staphylococcus aureus S. I. JACOBS and A. T. WILLIS

Identification and clinical significance of Klebsiella species in chest infections J. H. DARRELL and A. D. F. HURDLE

A vertical diffusion method for the microbiological assay of isoniazid JANET LLOYD and D. A. MITCHISON

Estimation of the low-density (beta) lipoproteins of serum in health and disease using large molecular weight dextran sulphate $\mathrm{K}$. W. WALTON and P. J. SCOTT

An automated method for serum magnesium estimation D. N. WHITMORE and D. I. K. EVANS

Spurious hyperkalaemia M. R. WILLS and I. D. FRASER

Changes in serum alpha $a_{2}$ globulins in reticuloses J. $\mathbf{s}$. MALPAS and G. HAMILTON FAIRLEY

Seromucoid, ground substance, and hypothyroidism ALLAN CAMPBELL, EWAN CAMERON, and ARTHUR MOLLISON
Seromucoid in lupus erythematosus and scleroderma R. K. PANJA, K. P. SENGUPTA, and B. K. AIKAT

Microbiological assay of folic acid activity in hums serum G. H. SPRAY

Folic acid clearances and basal serum folate levels $\underset{\mathbb{m}}{\stackrel{\Phi}{\Phi}}$ patients with thyroid disease JOHN LINDENBAUM amid FREDERICK A. KLIPSTEIN

Biochemical investigation of histidinaemia J. B. HoLTo $\underset{乛}{\overline{8}}$ F. J. W. LEWIS, and G. R. MOORE

Estimation of serum haemoglobin-binding capaciey (haptoglobin) on Sephadex G.100 A. P. RATCLIFF apd J. HARDWICKE

A study of Naphthionin in the management of the bleeding defect in patients with thrombocytopenia POLLER and J. R. S. MORE

Technical methods

Estimation of hydroxyproline by the AutoAnalys R. A. GRANT

Micro-method for the estimation of calcium by Auto. Analyser M. R. WILLS and B. C. GRAY

A mask facilitating multiple analyses by microimmuntelectrophoresis J. G. FEINBERG, K. L. G. GOLDSMITH, apd R. A. KEKWICK

Book reviews

Index to volume 17

Copies are still available and may be obtained from the PUBLISHING MANAGER, BRITISH MEDICAL ASSOCIATION, TAVISTOCK SQUARE, W.C.I., price 18s. 6D. 
doctors anxious to grasp the implications of this development, but it could be helpful to the few already grappling with bio-medical electronics and familiar with computer jargon. It should be of great value to those scientists engaged in the engineering of computers and related equipment. Most of the discussion is orientated around the application of computer techniques to the problem of automatically recording and interpreting electrocardiograms. This is a particularly difficult field but it serves well to illustrate that all those contemplating making use of a computer must formulate their problems in very exact terms.

This book is well produced and has an adequate index. Whether the verbatim presentation is preferable to a conventional report is a matter of opinion but the reviewer found the text stimulating and easy to assimilate. This is a book to be bought by the progressive medical library rather than by the individual pathologist.

$$
\text { F. V. FLYNN }
$$

A SYNOPSIS OF SURGICAL PATHOLOGY By Wilfred Kark. (Pp. 426; 26 figures. 45s.) Bristol: John Wright. 1964.

This pocket-sized book of lecture notes on surgical pathology contains unavoidable simplifications and omissions. Pathologists will regret these, but know how difficult it is to report pathological changes succinctly and completely, and will realize that Mr. Wilfred Kark often succeeds brilliantly with his brief descriptions of the morbid anatomy and histopathology of surgical diseases. The didactic annotated text can be read quickly and a lot of uncontroversial information obtained in a short time.

In this country the teaching of pathology is becoming more closely integrated with that of clinical practice, and few students should find this book essential. Pathologists are more likely to recommend it to their senior technician who helps with the surgical specimens than to medical students, and the fate of this new synopsis will depend upon the amount of goodwill it can generate among students who read this at the eleventh hour before their final examinations.

R. A. B. DRURY

\section{PROTIDES OF THE BIOLOGICAL FLUIDS}

The 13th annual colloquium on the Protides of the Biological Fluids will be held in Bruges on 29-30 April and 1-2 May 1965. Topics to be discussed are lipoproteins, proteins of the nervous system, and impedance measurements of the proteins. At 'round tables' the subjects to be discussed are the physical, chemical, and clinical method of lipoprotein analysis, and the proteins of the nervous system.

All information may be obtained from:-COLLOQUIUM, Protides of the Biological Fluids, जP.B. 71, Bruges, Belgium.

\section{Letter to the Editor}

Sir,

The report on exertional haemoglobinuria in the September 1964 issue of the Journal adds substance to an hypothesis proposed many years ago. In 1903 in the Transactions of the Royal Medical and Chirurgical Society of London (volume 86, page 165), C. W. Ensor and J. O. W. Barratt presented a case of 'Paroxysmal haemoglobinuria of traumatic origin'. The patient, a young man with schizophrenia, would lie on his hospital bed violently slapping his forehead for an hour or two, and haemoglobinuria would appear thereafter. The loss of haemoglobin was equivalent to that in 2 or $3 \mathrm{ml}$. of blood. This is, I believe, the only reported case of exertional haemoglobinuria associated with exercise of the upper extremities only. Ensor and Barratt proposed that the haemolysis occurred with the injuring of red cells by the violent slapping, a suggestion which anticipates Dr. Davidson's that exertional haemoglobinuria in runners results from mechanical damage to red cells in the soles of the feet.

$$
\begin{array}{r}
\text { Sincerely yours, } \\
\text { William H. Crosby, } \\
\text { Colonel, M.C. } \\
\text { Chief, Department of Hematology, } \\
\text { Walter Reed Army Medical Center, } \\
\text { Washington, D.C. }
\end{array}
$$

CORRECTIONS

Professor I. Friedmann (J. clin. Path., 18, 63-68) writes that his attention has been drawn to another case of rhabdomyosarcoma of the ear in a girl of 4 years which was described by Professor Dorothy Russell in her book written jointly with L. J. Rubenstein ('Pathology of tumours of the nervous system', 1st ed., 1959, page 215). This case has not been described separately in any journal.

In the note on page 134 (J. clin. Path., 18, 1965) it is stated that at the Midland Centre for Neurosurgery determinations of creatine kinase are being regularly carried out by Dr. D. A. Ellis with the support of the Muscular Dystrophy Group. While it is quite true that the Muscular Dystrophy Group have most generously supported Dr. Ellis in research on muscular dystrophy, the determinations of creatine kinase are carried out by Dr. R. A. Westhead in the Centre's biochemistry laboratory without assistance from the Muscular Dystrophy Group.

In the September issue of the paper by A. G. Baikie and E. M. Gillis (J. clin. Path., 17, 573-574) we regret that Figures 2 and 3 have been transposed. 